\title{
Community attitudes and preferences towards woody species: implications for conservation in Nawaikoke, Uganda
}

\author{
John R.S. Tabuti, T. Tíktin, M.Z. A rinaitwe and V.B. Munanika
}

\begin{abstract}
Worldwide many important tree resources, and the livelihoods of local community members who depend on them, are threatened. Effective management of tree resources requires, among other things, knowledge of which species are preferred locally and can therefore be successfully adopted into conservation plans, as well as an understanding of local attitudes towards tree conservation. We conducted a study in Nawaikoke Sub-county of eastern Uganda to address three questions: (1) Which woody species are considered most valuable to rural communities and how do priorities vary across different sectors of the communities? (2) What are local perceptions of the status of woody species and of the main threats to their conservation? (3) What attitudes do local people hold towards conservation and what challenges do conservation initiatives face? We carried out focus group discussions with different specialist groups, key informant interviews, and semi-structured interviews with 62 households. Our results illustrate that local communities value 26 woody species highly, 15 of which are indigenous. However, priorities vary greatly across different specialist user groups. According to respondents most of the prioritized species are threatened, with the greatest threats being charcoal burning, overexploitation and expanding agriculture. Community members are actively managing and/or interested in managing those tree resources with economic value but largely ignore the greater diversity of woody species, especially shrubs. Administrative, political and traditional leadership institutions do not currently assist in the conservation of woody species. We provide suggestions for a conservation action plan that involves multiple strategies.
\end{abstract}

Keywords Agroforestry, community attitudes, conservation status, priority species, trees, Uganda, woody species.

\section{Introduction}

ural people, especially in marginalized communities in The developing world, are highly dependant on wild

John R.S. TAButi* (Corresponding author), M.Z. Arinaitwe and V.B. MUWANiKa Institute of Environment and Natural Resources, Makerere University, P.O. Box 7298 Kampala. E-mail jtabuti@muienr.mak.ac.ug

T. TickTin Department of Botany, University of Hawaii, Honolulu, Hawaii. ${ }^{\star}$ Also at: Department of Botany, Makerere University, Kampala, Uganda.

Received 6 October 2007. Revision requested 16 February 2008. Accepted 19 May 2008. trees and other woody species (Kala et al., 2004; Ticktin, 2004) from which they harvest products that include fuelwood, construction wood, edible fruits and medicines (Walter, 2001; Tabuti et al., 2003a,b, 2004). These products are used in the home and also sold, contributing to household income. Cash income from plants can supplement subsistence agriculture, help conserve family assets, and is particularly significant for rural women (Konstant et al., 1995; Shackleton et al., 2001). In Uganda dependence on wild plants, especially trees, is widespread. It has been estimated that $90 \%$ of Ugandans depend on fuelwood for energy needs and that c. 1 million earn their income from forest products (NEMA, 2002).

As elsewhere, trees in Uganda, especially wild trees, are threatened and are declining in abundance and diversity (NEMA, 2002). Between 1890 and 2002 forested areas and woodlands decreased from 52 to $24 \%$ of Uganda's land area, and woody biomass is disappearing at an estimated annual rate of $3 \%$ (NEMA, 2002). The main factor responsible is rapid human population growth (3.4\% per annum; NEMA, 2002) and associated agricultural expansion and overexploitation. Overexploitation of woody species continues because the country is experiencing a rising demand for wood products for both domestic and commercial purposes (NEMA, 2002). In addition, $70 \%$ of the woody plants of Uganda occur on private land outside protected areas (NEMA, 2002) and landowners tend not to be interested in biodiversity conservation because it contributes little to their livelihoods.

Although many plant species are prone to unsustainable harvesting, woody plants are especially vulnerable because of their longevity, large size, poor dispersal capacities and low reproductive rates (Díaz et al., 2006). These characteristics render them susceptible to local extinction. Overexploitation is influenced by patterns of plant resource use, which are influenced by cultural, economic and political factors (Hall \& Bawa, 1993; Peters, 1999; Ticktin, 2004).

The loss of important traditional tree resources may threaten livelihoods and increase poverty among local communities. It is therefore important that such species are managed sustainably. This requires information to aid resource managers and others in decisions regarding which species to conserve and how most effectively to encourage collaboration with communities (Warner, 1999). Such information includes knowledge of locally valued and preferred tree species, local perceptions of trends in resource 
status and conservation, and information on attitudes towards conservation and local management practices (Martin, 1995; Lykke, 1998, 2000; Obiri et al., 2002; Tabuti, 2007).

In the study reported here we addressed the following questions: (1) Which woody species are considered most valuable to rural communities in Nawaikoke Sub-county, Uganda, and how do priorities vary across different sectors of the communities? (2) What are local perceptions of the status of woody species and of the main threats to their conservation? (3) What attitudes do local people hold towards conservation and what challenges do conservation initiatives face? We discuss the implications of our results for conservation of woody species in Nawaikoke and elsewhere.

\section{Study area}

Nawaikoke Sub-county is in Kaliro District, eastern Uganda, c. $200 \mathrm{~km}$ north-east of Kampala, and has an area of c. $185 \mathrm{~km}^{2}$ (excluding wetlands; Fig. 1). It is administered through elected local council committees, headed by chair- persons at the various administrative levels. The Sub-county level is Local Council Level 3; the lowest administrative division is the village level, referred to as Local Council 1. The landscape is relatively flat, at altitudes of $1,045-1,075 \mathrm{~m}$, the climate is hot and dry, and total annual rainfall is $1,195-1,357$ $\mathrm{mm}$ and is bimodal (UBoS, 2000). There are two dry seasons, October-March and June-July. Nawaikoke has a number of rocky hills that are not suitable for crop agriculture but that serve as important habitat for plants. The original vegetation consisted of Cyperus papyrus, Combretum-Hyparrhenia rufa dry savannah swamps, Combretum-Terminalia-Albizia zygia-Hyparrhenia rufa moist savannah and Sorghastrum grasslands on sites of impeded drainage (Langdale-Brown et al., 1964).

The landscape is a mosaic of open woody vegetation comprising woody fallows of different ages and farmland used for small-scale subsistence agriculture. The latter dominates the landscape. Traditional subsistence agricultural practices consist of clearing land, cultivating it, and abandoning it to fallow for varying periods of time. Fallows

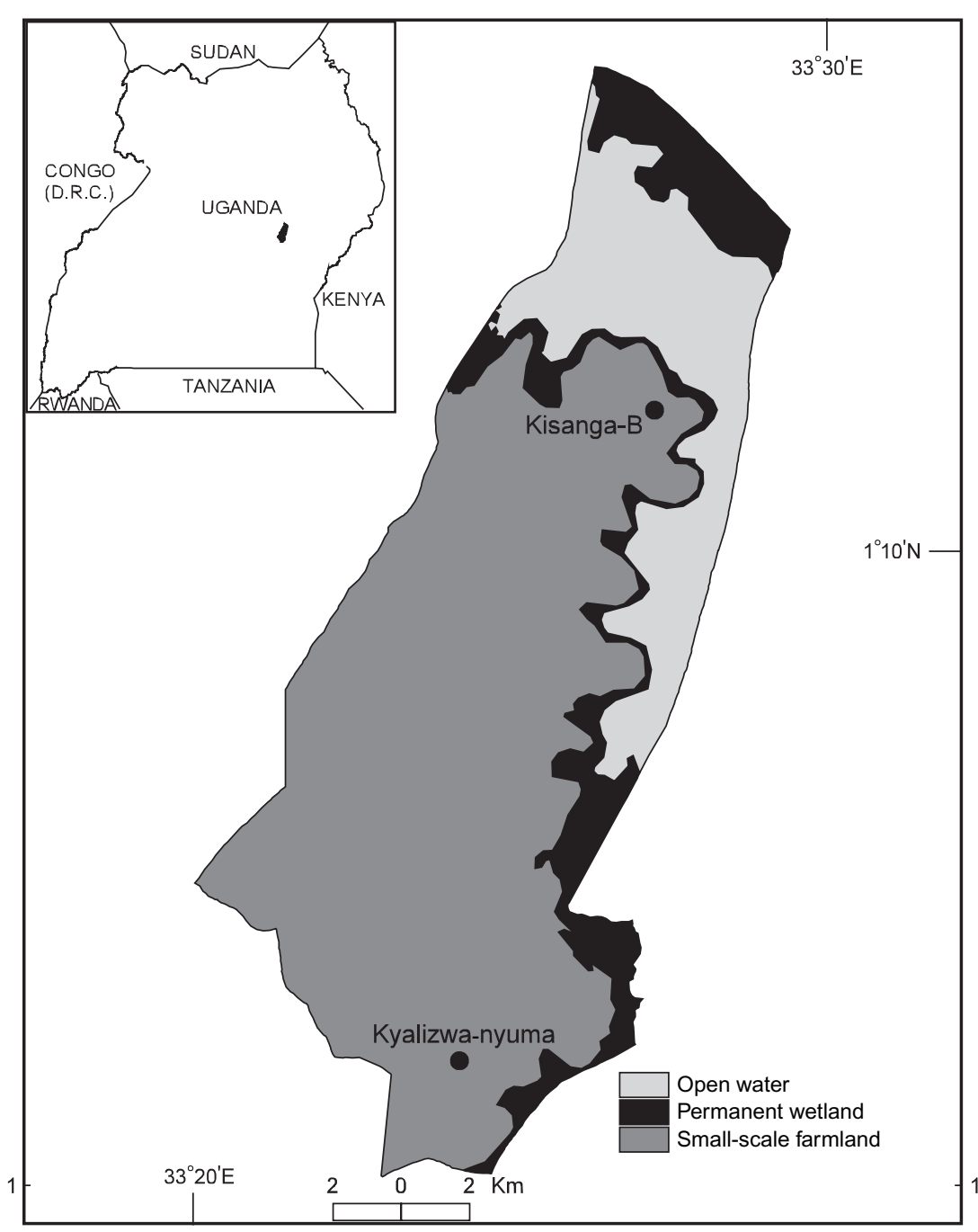

FIG. 1 Nawaikoke Sub-county, with the location of the two villages in which interviews were carried out. The inset shows the location of the main map in eastern Uganda. 
of different ages intergrade into the woodlands, bush, grasslands and wetlands. The length of the fallow period has declined in the last 4 decades (NEMA, 2002). Other land uses include grazing and settlements. Average plot size is c. 2 ha per homestead.

The Balamogi constitute the dominant ethnic group, followed by the Bakenye and Ateso. Other ethnic groups include the Banyarwanda, Sebei, Baganda and Bagisu. Nawaikoke has a population of c. 40,000 people and a population density of $>210$ people per $\mathrm{km}^{2}$ (Uganda Bureau of Statistics, unpubl. data). The average household size is five, of whom $58 \%$ are $0-17$ years and $19 \% 18-30$ years.

The major source of income is subsistence farming, with $87 \%$ of the community thus engaged, cultivating cassava, potatoes, cereals (maize, millet), groundnuts and cotton. Rice is grown seasonally on flooded wetlands, and people engage in small-scale businesses and fishing. Six percent of households depend on family remittances from relatives living in cities. Other sources of livelihood include salaried employment $(3 \%)$ and cottage industries ( $1 \%)$. Livestock is an important store of wealth (Uganda Bureau of Statistics, unpubl. data). There is high dependence on woody plants for house construction. Roofs and walls are constructed of natural materials: $>68 \%$ of all houses are roofed using thatch, and $32 \%$ of houses are constructed using burnt stabilized bricks (which use wood), 15\% mud and poles, and $1 \%$ wood. A substantial proportion of the population depend on traditional medicines derived from plants (Tabuti et al., 2003b).

\section{Methods}

Field work was conducted from September 2006 to August 2007. To assess which woody species are most valuable to different sectors of the communities, and local perceptions of, and attitudes towards, woody species, we used a combination of group interviews, focus group discussions, individual interviews with key informants, household interviews and list-scoring, and preference-ranking techniques. We also used direct observation to complement these data.

We started with a meeting with the political head of Nawaikoke Sub-county (Local Council 3 Chairman). The study and its objectives were explained, permission was requested (and granted), and the Chairman suggested Kyalizwanyuma village, where people are mostly dependent on agriculture, for the first group interview. The objective of the group interview was to generate a list of woody, rare (according to local perceptions) and preferred species. The benefits derived from trees, current threats to tree conservation and existing management practices were also discussed. The group interview was then repeated in Kisanga-B village, chosen because we knew it has lower woody species abundance and the inhabitants engage in fishing and trade. Thirty-four people participated in the Kyalizwa-nyuma group interview (19 men, 15 women) and 15 (all men) in the Kisanga-B group interview.

For the key informant interviews two village elders in Kyalizwa-nyuma village were identified and, in a semistructured interview, were asked about historical changes in species' uses, ecological changes, and traditional management practices. Three local politicians (one Local Council 3 and two Local Council 1 Chairpersons) were asked questions about the area, such as perceptions of threats to tree resources. This information was then used in the design of the household survey interviews.

To identify how preferences for woody species vary, focus group discussions were held with traditional medicine practitioners, homestead members, builders, carpenters and craft makers of Kyalizwa-nyuma village. In each discussion participants were asked the same series of questions relating to threats, attitudes towards species conservation and perceptions of the conservation status of species. Threats were assessed on the basis of local perceptions of species' abundances and observed temporal changes in abundance. Local perceptions of abundance were scored as very rare, rare, abundant and very abundant. Changes in abundances were scored either as increasing or decreasing. Participants were also asked to rank their preferred species using the listscoring method (Sheil et al., 2003), in which participants state the list of species they consider the most important and are then given 100 pebbles that they are asked to distribute amongst the listed species to portray their relative importance. Following these participatory approaches, short lists of preferred species, threats and constraints to tree conservation, and opportunities to conserve trees were generated.

In the final stage of data collection a guided questionnaire for household interviews was designed based on the information gathered from the group interviews, focus group discussions and key informant interviews. It was then tested in a pilot study, following which the short list of preferred species was expanded to include more species. This questionnaire comprised a series of questions on demography (age, sex, education), and open-ended questions related to perceptions of species' availability and populations status, the help people need to conserve trees, suggestions for strengthening tree conservation, and whether anyone had ever encouraged them to plant, manage or conserve trees. The questionnaire included a section in which respondents were asked to rank species from a short list of preferred species using the preference-ranking method described in Martin (1995). Similarly, respondents were asked to rank a short list of threats to tree conservation, and problems and opportunities for tree conservation.

We interviewed 62 respondents (20 female). We had originally planned to select the respondents randomly but in the pilot study we discovered this was too demanding logistically and instead we requested the local area leaders to identify a representative sample of respondents. Although 
we aimed for a gender balance, the number of female respondents was less because women were reluctant to be interviewed.

Data from the questionnaire survey were summarized into percentages. All preference rankings were averaged across the respondents and ranked in ascending order. In this way the most important species, threats and constraints were assigned the lowest numerical value. Differences in number of species categorized by levels of perceived abundance and whether this was independent of status (increasing or decreasing) were assessed using $\chi^{2}$ tests. Fisher's exact tests were used to test if tree planting was independent of perceived abundance, status and nativeness (indigenous or naturalized). Similarly, Fisher's exact tests were used to test the independence of perceived abundance and nativeness.

We also tested if there were differences in the proportion of respondents planting, retaining and wishing to plant indigenous versus non-indigenous (naturalized and alien) species, increasing versus decreasing species, and rare (very rare or rare) versus abundant (abundant or very abundant) species. When data sets met the assumptions of normality and homogeneous variances one-way ANOVAs were used, otherwise Kruskal-Wallis tests were used.

\section{Results}

\section{Priority woody species}

During group discussions participants reported the existence of $>150$ woody species. Twenty-six of these were prioritized during the focus group discussions and questionnaire survey as the most valuable (Table 1), and these were ranked using the household surveys. Most of the 26 species are multi-purpose; their major products and uses include herbal medicines, wood for timber and house construction, edible fruit, shade, charcoal and firewood. Fifteen of the prioritized species are indigenous and are naturally regenerating (Table 1). Only four of the 26 (15\%; Table 1) are truly exotic (sensu Bosch \& Borus, 2006).

There were differences in perceptions of the relative value of species (Fig. 2). While craft-makers prefer Maesopsis eminii, carpenters and builders prefer Milicia excelsa, and the non-specialist plant users prefer Eucalyptus spp.. The priority species identified by the healers, who identified 30 important medicinal species but chose to rank only seven, are not valued by any other group. The most important species for the healers was Psorospermum febrifugum, which is used for the treatment of skin disease ailments. Markhamia lutea and Psydrax parviflora subsp. parviflora were prioritized only by builders, Combretum collinum and Mangifera indica only by households, and Ficus natalensis only by craft-makers. Of the 17 species prioritized by the focus group interviews with specialist groups, only five $(29 \%)$ were prioritized by more than one group.

\section{Community perceptions of threats to woody species}

During the group interviews it was generally agreed that many wild woody species are threatened and declining in availability and distribution. The household questionnaire revealed that the number of species reported varied significantly among the perceived risk categories, i.e. $41 \%$ of species were perceived to be rare, and only a few $(4 \%)$ perceived to be very abundant $\left(\chi^{2}=8.407, \mathrm{df}=3, \mathrm{P}=0.03\right.$; Table 1). Overall, $>60 \%$ of the 26 species were perceived to be either very rare or rare (Table 1 ).

Perceived abundance of indigenous and naturalized species varied significantly (Fisher's exact test: $n=22$, $\mathrm{df}=1, \mathrm{P}=0.017$ ), with $\mathrm{c} .70 \%$ of the indigenous species perceived to be either rare or very rare versus $22 \%$ of the naturalized species. Significantly more indigenous species were reported to be decreasing than naturalized species ( $23 \%$ vs $14 \%$; Fisher's exact test: $\mathrm{n}=20, \mathrm{df}=1, \mathrm{P}=0.017$ ). Of species perceived to be very rare or rare $75 \%$ were also perceived to be declining, whereas only $10 \%$ of those species reported to be abundant or very abundant were perceived to be declining $\left(\chi^{2}=10.01, \mathrm{df}=1, \mathrm{P}=0.0013\right)$.

Practices ranked most highly as having a negative impact on tree survival include charcoal burning, habitat conversion of off-farm lands to crop agriculture, overexploitation of trees to produce wood for housing, timber and brick burning, and poor management (Table 2). Respondents indicated that high levels of poverty were forcing them to harvest trees destructively for products to sell. Diseases and pests were also mentioned as causes for the loss of trees.

During focus group discussions and preference-ranking exercises during guided questionnaire interviews it became clear that the extensive harvesting of wood for charcoal production and clearing of fallowing lands for agriculture were the most significant factors contributing to tree loss (Table 2, Fig. 3). Charcoal burners harvest a lot of wood, especially of small-sized trees. Farmers are expanding agriculture and destroying woody species perceived to be of low value to free land for subsistence and commercial food crops. It was reported that selling of food crops is a new practice; food was previously grown for subsistence only. Farmers have also introduced new crops, such as rice, in seasonally flooded habitats that were previously considered unsuitable for cultivation and, as a result, were an important refuge for woody species.

\section{Attitudes towards conservation of woody species and management practices}

All the people interviewed were willing to conserve woody species. More than $90 \%$ of the respondents had planted and also retained naturally growing trees on their land (Fig. 4). Some own wood-lots of exotics such as Eucalyptus spp.. It 
TABLE 1 The 26 woody species prioritized during focus group discussions with traditional medicine practitioners, homestead members, builders, carpenters and craft-makers of Kyalizwa-nyuma village, and with key informants. Local perceptions of some attributes of the species and major uses are also shown.

\begin{tabular}{|c|c|c|c|c|}
\hline Species & Nativeness & Major use & Perceived status & Perceived availability \\
\hline Milicia excelsa (Welw.) C.C. Berg & Indigenous & Timber, house construction & Decreasing & Rare \\
\hline Mangifera indica $\mathrm{L}$. & Naturalized & Food & Increasing & Very abundant \\
\hline Maesopsis eminii Engl. & Indigenous $^{1}$ & Timber, house construction & Decreasing & Rare \\
\hline Persea americana Mill. & Naturalized & Food & Decreasing & Rare \\
\hline Eucalyptus spp. & Exotic & Timber, house construction & Increasing & Rare \\
\hline Citrus $\times$ aurantium L. $^{2}$ & Naturalized & Food & Increasing & Abundant \\
\hline Artocarpus heterophyllus Lam. & Naturalized & Food & Increasing & Abundant \\
\hline Ficus natalensis Hochst. & Indigenous & Shade & Increasing & Abundant \\
\hline Terminalia spp. & Indigenous $^{1}$ & Shade & Increasing & Very rare \\
\hline Melia azedarach $\mathrm{L}$. & Naturalized & Timber, house construction & Increasing & Rare \\
\hline Markhamia lutea (Benth.) K. Schum. & Indigenous & Timber, house construction & Decreasing & Rare \\
\hline Azadirachta indica A. Juss. & Exotic & Medicinal & Increasing & Rare \\
\hline Casuarina spp. & Exotic & Shade & Decreasing & Very rare \\
\hline Albizia coriaria Welw. ex Oliv. & Indigenous & Timber, medicinal, charcoal & Decreasing & Rare \\
\hline Moringa oleifera Lam. & Exotic & Medicinal & Increasing & Abundant \\
\hline Sarcocephalus latifolius (Sm.) Bruce ${ }^{2}$ & Indigenous & Medicinal & Decreasing & Very rare \\
\hline Securidaca longipedunculata Fresen. & Indigenous & Medicinal & Decreasing & Rare \\
\hline Terminalia glaucescens Planch. ex Benth. & Indigenous & Medicinal & Decreasing & Rare \\
\hline Psorospermum febrifugum Spach $^{2}$ & Indigenous & Medicinal & Decreasing & Very rare \\
\hline Senna siamea (Lam.) H.S. Irwin \& Barneby & Naturalized & House construction & Increasing & Abundant \\
\hline Senna spectabilis (DC.) H.S. Irwin \& Barneby & Naturalized & Firewood & Increasing & Abundant \\
\hline Psydrax parviflora subsp. parviflora ${ }^{2}$ & Indigenous & Firewood & Decreasing & Rare \\
\hline Acacia seyal Delile & Indigenous & Medicinal & Increasing & Abundant \\
\hline Combretum collinum Fresen. & Indigenous & Firewood, charcoal & Decreasing & Abundant \\
\hline Ficus sycomorus L. & Indigenous & Shade & Increasing & Abundant \\
\hline Ziziphus pubescens Oliv. & Indigenous & Medicinal & Decreasing & Very rare \\
\hline
\end{tabular}

${ }^{1}$ Indigenous to Uganda but not to Nawaikoke Sub-county

${ }^{2}$ Shrub

was reported that planting of trees is a break from past practice, when it was taboo to plant and only a few species were planted, such as Dracaena fragrans and Jatropha curcas for land demarcation, $F$. natalensis for barkcloth making, and Euphorbia candelabrum and Euphorbia tirucalli as homes for spirits. Trees planted by at least $40 \%$ of the farmers are crop trees and these include the edible fruit-bearing M. indica, Artocarpus heterophyllus and Citrus $\times$ aurantium. F. natalensis is valued for its shade and is mostly planted and protected for this purpose. Whether a species is planted or not is independent of its perceived abundance, status and nativeness $(\mathrm{P}>0.05$ in all cases). Those tree species that are not currently planted or are planted by $<10 \%$ of respondents include $50 \%$ of the indigenous trees, $46 \%$ of the trees perceived to very rare or rare, and $50 \%$ of trees perceived to be decreasing.

A significantly higher proportion of respondents planted and retained non-indigenous (naturalized or alien) than indigenous species, although there were no significant differences between the proportion of individuals wishing to plant indigenous versus non-indigenous species, species perceived to be increasing rather than decreasing, and species reported to be rare rather than abundant (Table 3).
However, the proportion of respondents wishing to plant trees was significantly higher for rare than for abundant species (Table 3).

Trees that are most frequently retained are M. excelsa, C. collinum and Ficus sycomorus. Juvenile trees of these species are protected against livestock-browsing by fences of thorny plants. Another practice is to avoid tethering animals to stems of preferred species. Trees retained by $>60 \%$ of respondents are Persea americana, Azadirachta indica, Eucalyptus spp. and Terminalia spp.. Trees are also protected by restricting access of wood harvesters. Species valued for their timber, such as $M$. excelsa, cannot be harvested without the owner's permission.

Farmers are ready to propagate species other than the commonly planted or protected trees. The species desired for planting by most people include Eucalyptus spp., Terminalia spp. and A. indica. Despite their willingness to establish and manage trees, farmers are constrained by several factors. These include poverty, and lack of seedlings and land (Table 4). Poverty discourages tree planting because people lack the means to purchase material for tree establishment. When asked what help the farmers would need to overcome such problems and improve conservation 


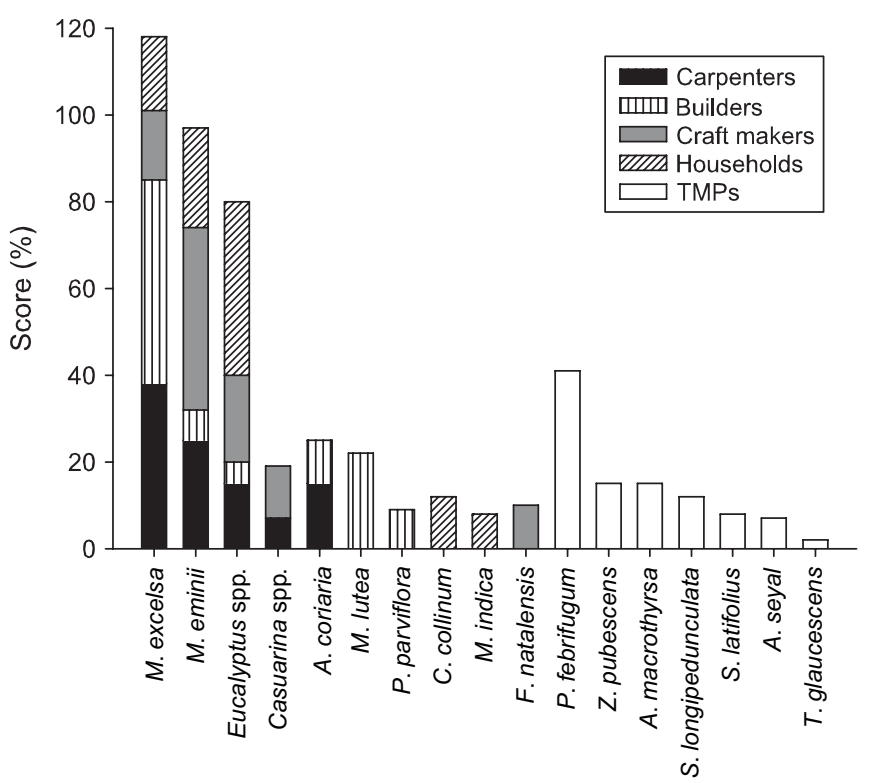

FIG. 2 The 17 species prioritized by specialist plant user groups. Scores were obtained using the list-scoring method (Sheil et al., 2003; see text for details) during focus group discussions. TMPs, traditional medicine practitioners. The species Acacia macrothyrsa Harms (Muhologoma) was mentioned by TMPs only and does not appear in Table 1.

of trees, most requested seedlings, pesticides and farming equipment (Fig. 5). They also said that increasing awareness about the importance of tree conservation was important. Level of awareness is low and only seven respondents claimed anyone had ever advised them to plant trees.

TABle 2 Local practices, attitudes and ecological factors that threaten woody species, as reported by residents of Nawaikoke Sub-county. Ranks are based on averages from the household interviews (1 represents the highest threat).

\begin{tabular}{lc}
\hline Factor & Rank \\
\hline Harvesting of wood for charcoal burning & 1 \\
Clearance of woody vegetation on off-farm lands & 2 \\
$\quad$ to prepare fields for agriculture & \\
Harvesting of wood for house construction & 3 \\
Harvesting of wood for timber & 4 \\
Harvesting of fuelwood for brick firing & 5 \\
Poverty & 6 \\
Harvesting of firewood & 7 \\
Farmers are not planting trees & 8 \\
Drought & 9 \\
Livestock browsing of seedlings and saplings & 10 \\
Tree pests & 11 \\
Human population growth & 12 \\
Tree diseases & 13 \\
Lack of planting material & 14 \\
Low awareness about policies and legislation & 15 \\
Poor management of trees & 16 \\
Perception that some species are of low value & 17 \\
Tethering animals to living trees & 18 \\
\hline
\end{tabular}

\section{Discussion}

\section{Priority woody species}

The woody species that are popular with farmers of Nawaikoke include 26 species, 15 of which are indigenous. These priority species are valued for both subsistence and commercial purposes. This list is an important resource for stakeholders interested in agroforestry and reforestation because the trees that can be most successfully promoted for cultivation by farmers are those that can satisfy local community needs and priorities (Warner, 1999).

There is much variation in the prioritization of woody species by different specialist users. For example, the species prioritized by traditional medicine practitioners are undervalued by other people. This means that such species are vulnerable to destruction by those who do not attach priority to them. Five of the six indigenous medicinal trees are considered by the local inhabitants to be rare or very rare and decreasing in abundance. In an area where c. $60 \%$ of the inhabitants depend on traditional medicines (Tabuti et al., $2003 \mathrm{~b}$ ) this has important consequences and illustrates the importance of ensuring that the perspectives of all sectors of society are included when designing programmes to foster community tree propagation and conservation.

\section{Perceptions of threats to woody species}

The majority of priority woody species reported here were perceived by respondents to be very rare or rare, and significantly more indigenous than naturalized species were perceived to be rare and to be decreasing in abundance. As has been reported elsewhere, the major threats to trees include charcoal burning, habitat conversion and overexploitation through destructive harvesting of wood (WRI et al., 1992; NEMA, 2002). Species most at risk of being overexploited include multi-purpose trees preferred by many specialist users or those with potential to satisfy many different uses. Small trees and shrubs and large trees that are not greatly valued in Nawaikoke are also at risk as many are overharvested for the production of charcoal for sale. Other tree species suffer from habitat destruction; for example, the expansion of crop agriculture into seasonally flooded wetlands is the most probable cause of the rapid decline of the rare and locally important medicinal woody shrub Sarcocephalus latifolius. The expansion of agriculture has also led to a reduction in areas and periods of fallow, which are important for maintaining tree species diversity in anthropogenic landscapes (Augusseau et al., 2006).

Destructive practices such as charcoal burning and habitat conversion are likely to intensify in Nawaikoke Sub-county because of the rapidly growing human population (UboS, 2005) and hence increasing demand for charcoal, the most important fuel for domestic cooking 


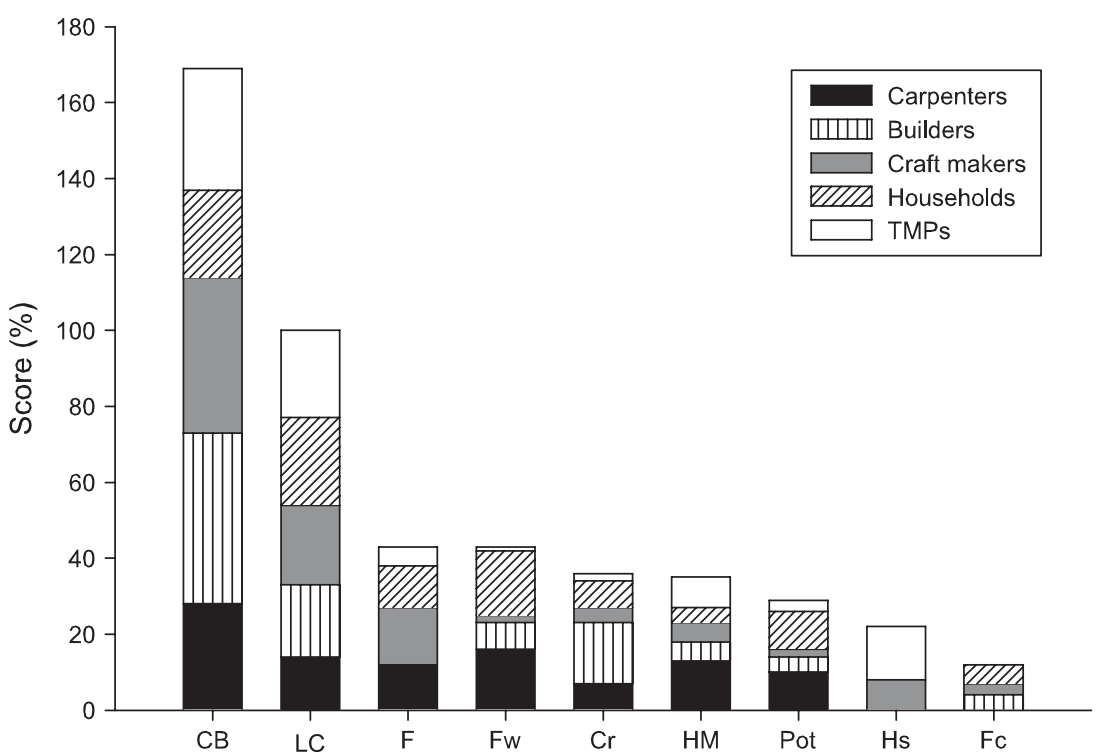

FIG. 3 The most destructive practices threatening woody plant survival as reported by specialist plant users in focus group discussions. Scores were obtained using the list-scoring method (Sheil et al., 2003; see text for details). TMPs, traditional medicine practitioners; $\mathrm{CB}$, charcoal burning; $\mathrm{LC}$, land clearance for agriculture; $\mathrm{F}$, furniture construction; Fw, fuelwood collection; $\mathrm{Cr}$, craft making; HM, harvest of herbal medicines; Pot, pot making; Hs, house construction; Fc, construction of fishing craft (e.g. oars).
(Tabuti et al., 2003a). Poverty, low formal education and lack of pragmatic alternatives to earn cash will also probably lead people to rely more on natural resources for income generation (references in Twine, 2005). Finally, as elsewhere, the decline in abundance of certain tree species appears to have increased their commercial value, which

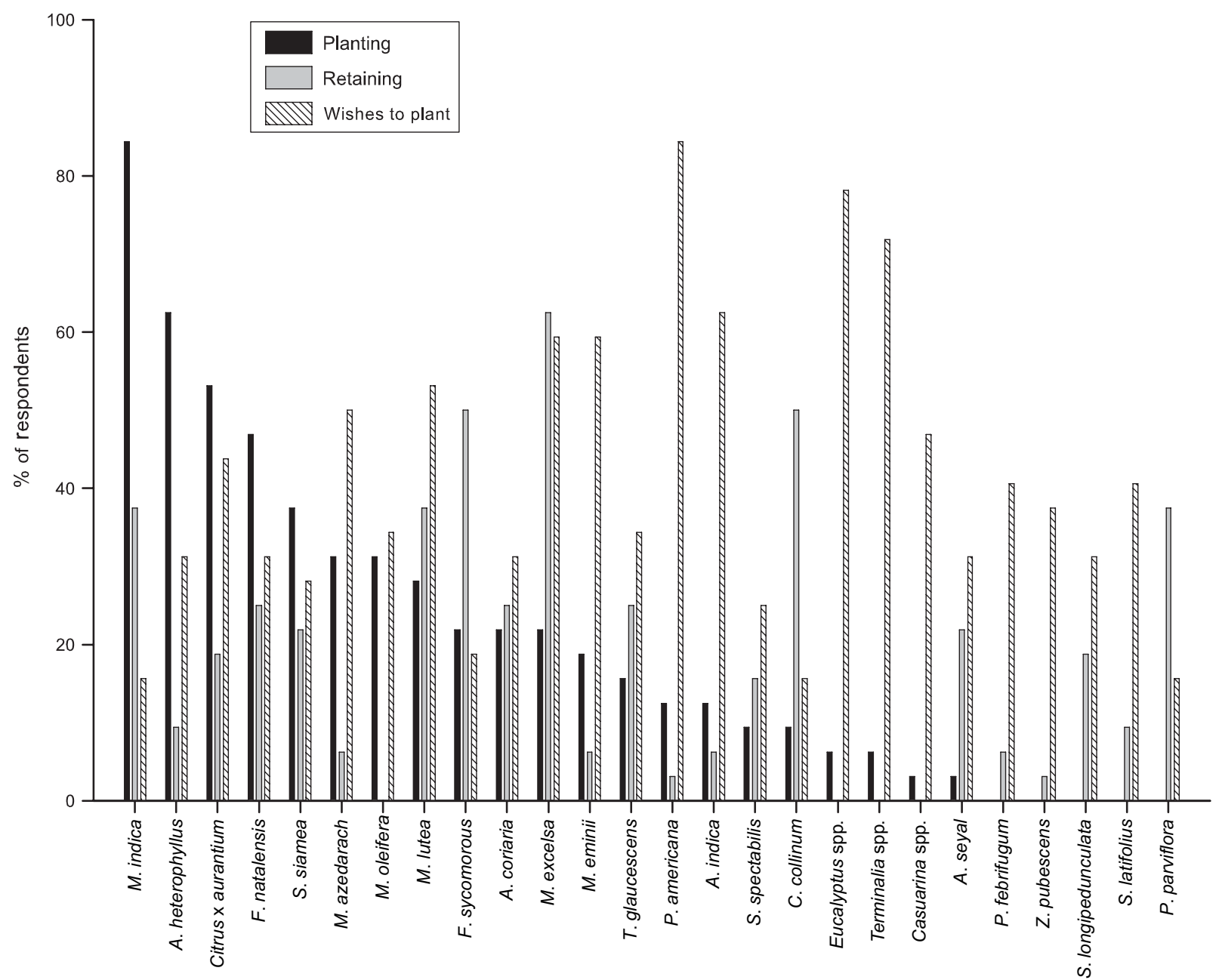

FIG. 4 Percentage of respondents retaining, planting or interested in planting the most highly valued tree species (Table 1) in Nawaikoke Sub-county, ordered by decreasing percentage wishing to plant. 
TABLE 3 The percentage of respondents planting, retaining, or wishing to plant the most highly valued tree species in Nawaikoke Subcounty according to their nativeness, perceived status and perceived abundance. Values represent means \pm 1 SE. Values in bold indicate significant differences $(\mathrm{P}<0.05)$.

\begin{tabular}{|c|c|c|c|c|c|c|c|c|c|}
\hline & \multicolumn{3}{|l|}{ Nativeness } & \multicolumn{3}{|c|}{ Perceived status } & \multicolumn{3}{|c|}{ Perceived abundance } \\
\hline & Indigenous & Non-indigenous & $P$ value & Increasing & Decreasing & $P$ value & Abundant & Rare & $P$ value \\
\hline Planting & $12.92 \pm 3.33$ & $31.25 \pm 9.42$ & 0.03 & $31.25 \pm 8.67$ & $10.10 \pm 2.80$ & $0.01^{\star}$ & $35.93 \pm 8.28$ & $11.13 \pm 2.69$ & $0.008^{\star}$ \\
\hline Retaining & $25.21 \pm 6.50$ & $10.80 \pm 3.25$ & 0.04 & $16.35 \pm 4.53$ & $21.87 \pm 6.07$ & 0.78 & $25.00 \pm 15.19$ & $15.43 \pm 4.46$ & $0.12^{\star}$ \\
\hline Wishing to plant & $38.13 \pm 9.84$ & $45.45 \pm 13.70$ & 0.34 & $40.14 \pm 11.13$ & $42.31 \pm 11.73$ & 0.43 & $27.50 \pm 2.82$ & $49.80 \pm 4.68$ & $0.002^{\star}$ \\
\hline
\end{tabular}

${ }^{*}$ Tested using Kruskal-Wallis tests. All other tests were with one-way ANOVAs.

may result in an inflation of local prices and motivate an increasing number of people to harvest trees (Twine, 2005).

The loss of traditional cultural norms has also contributed to the loss of trees. Access to some tree species was formerly regulated by local beliefs, and certain species and habitats were protected from exploitation by taboos. One of several species protected was E. candelabrum, believed to contain home spirits, and harvesting was therefore taboo. Just before this study started, however, a tree believed to house the spirit of Nansololo village was felled.

The institutional infrastructure to regulate tree conservation is weaker than it was during the colonial period, when the state regulated exploitation of woody species though the local administration and there was an extension service influential in encouraging tree planting on government land. Although structures now exist for the protection of the environment, respondents regarded them as ineffective for tree conservation.

\section{Attitudes towards conservation of woody species}

Given the current threats to woody species in Nawaikoke and the predicted increase in charcoal burning and habitat loss, there is a great need for conservation plans for woody

TABLE 4 Constraints to conservation of trees in Nawaikoke Subcounty. Rankings were averaged from the household interviews (1 represents highest constraint).

\begin{tabular}{lc}
\hline Problem & Ranking \\
\hline Poverty & 1 \\
Lack of seedlings & 2 \\
Lack of land & 3 \\
Animal browsing & 4 \\
Drought & 5 \\
Does not know how to propagate & 6 \\
Tree diseases & 7 \\
Tree pests & 8 \\
Bush fire & 9 \\
Lack of equipment & 10 \\
Lack of labour & 11 \\
Low motivation & 12 \\
\hline
\end{tabular}

species. Our results show that the community members of Nawaikoke Sub-county are interested in conserving trees. Some valued species, such as Eucalyptus spp. and M. eminii, although known to be rare, are reported to be increasing specifically because people are planting them. In addition, the reason that some prioritized species are perceived to be increasing and/or abundant is because they are planted. The proportion of respondents expressing a desire to plant trees was also significantly higher for rare than for already abundant species. These attitudes provide an opportunity to promote conservation.

However, tree conservation in Nawaikoke faces some challenges. As elsewhere, farmers in Nawaikoke are currently managing, or interested in managing, only relatively few species whilst neglecting the wider diversity of trees (Augusseau et al., 2006). For example, only about half of the indigenous species are currently being planted and a greater proportion of respondents are planting non-indigenous than indigenous species. Species that have little or no market value are largely ignored by farmers (Schippman et al., 2002). In addition, the capacity of farmers to establish and maintain trees is challenged by poverty, lack of seedlings, and lack of knowledge on propagation and care for

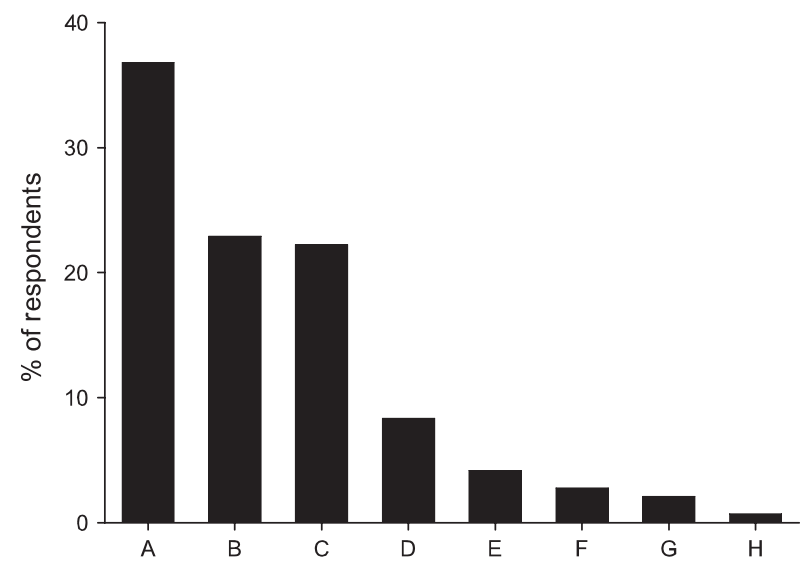

FIG. 5 Percentage of respondents requesting various types of assistance to establish and manage trees. $\mathrm{A}=$ seedlings; $\mathrm{B}=$ knowledge of how to propagate and care for trees; $\mathrm{C}=$ pesticides; $\mathrm{D}=$ equipment; $\mathrm{E}=$ money to purchase equipment and other farm material; $\mathrm{F}=$ land; $\mathrm{G}=$ fertilisers; $\mathrm{H}=$ labour. 
trees. State, local and traditional institutions will need to help address this.

The major challenge to promoting conservation of woody species in Nawaikoke, as elsewhere, continues to be that identified by Augusseau et al. (2006): how can farmers be motivated to conserve diversity? One solution may be the development of an action plan with multiple strategies. For Nawaikoke we propose this should include: (1) participatory planning for resource conservation with the local community based on prioritized species and locally recognized threats; (2) where opportunities for maintaining fallows exist, they should be enriched with useful indigenous tree species to transform them into economically useful land units (Augusseau et al., 2006); (3) a policy should be created by the local administration to set aside protected areas for biodiversity conservation, to include land areas unsuitable for cropping and involve conservation of those trees that may not be local priorities but that have important ecological functions; and (4) local institutions, traditional cultural values and norms that foster conservation should be strengthened as they can play important roles in biodiversity conservation (Gadgil et al., 1993).

Our results point to several avenues of further research. Population surveys of the species reported are required for comparisons with local perceptions, and will be critical for providing information on conservation priorities. Effective methods are required for propagation of those indigenous species not currently planted, particularly those reported to be rare and/or decreasing. Lastly, our research needs to be expanded. We report on only one Sub-county, but the need to identify approaches and priorities for fostering better local conservation of woody species extends throughout Uganda.

\section{Acknowledgements}

We acknowledge with gratitude the people of Nawaikoke Sub-county for participating in the interviews. We also thank our field assistants Charles Wambuzi and Rose Akello (RIP). This study was sponsored by Makerere School of Graduate Studies (Project No. Mak/2006/0162). Additional support was received from COMPAS (Comparing and Supporting Endogenous Development) and a local NGO, Sustainable Use of Plant Diversity. Permission to conduct the study was granted by the Uganda National Council for Science and Technology (NS 97).

\section{References}

Augusseau, X., Nikiéma, P. \& Torquebiau, E. (2006) Tree biodiversity, land dynamics and farmers' strategies on the agricultural frontier of south-western Burkina Faso. Biodiversity and Conservation, 15, 613-630.
BACKes, M.M. (2001) The role of indigenous trees for the conservation of biocultural diversity in traditional agroforestry land-use systems: the Bungoma case study: in situ conservation of indigenous tree species. Agroforestry Systems, 52, 119-132.

Bosch, C.H. \& Borus, D.J. (eds) (2006) Dyes and Tannins of Tropical Africa. Conclusions and Recommendations Based on PROTA 3: 'Dyes and Tannins'. PROTA Foundation, Wageningen, The Netherlands.

Díaz, S., Fargione, J., Chapin, F.S. \& Tilman, D. (2006) Biodiversity loss threatens human well-being. PLoS Biology, 4, e277.

Gadgil, M., Berkes, F. \& Folke, C. (1993) Indigenous knowledge for biodiversity conservation. AMBIO, 22, 151-156.

Hall, P. \& BAWA, K. (1993) Methods to assess the impact of extraction of non-timber tropical forest products on plant populations. Economic Botany, 47, 234-247.

Hulme, D. \& Shepherd, A. (2003) Conceptualizing chronic poverty. World Development, 31, 403-423.

Kala, C.P., Farooquenn, N.A. \& Dhar, U. (2004) Prioritization of medicinal plants on the basis of available knowledge, existing practices and use value status in Uttaranchal, India. Biodiversity and Conservation, 13, 453-469.

Konstant, T.L., Sullivan, S. \& Cunningham, A.B. (1995) The effects of utilization by people and livestock on Hyphaene petersiana (Arecaceae) basketry resources in the palm savannah of north-central Namibia. Economic Botany, 49, 345-356.

Langdale-Brown, I., Osmaston, H.A. \& Wilson, J.G. (1964) The Vegetation of Uganda and its Bearing on Land-use. Government of Uganda, Kampala, Uganda.

LYKKE, A.M. (1998) Assessment of species composition change in savannah vegetation by means of woody plants' size class distributions and local information. Biodiversity and Conservation, 7, 1261-1275.

LYKKе, A.M. (2000) Local perceptions of vegetation change and priorities for conservation of woody savannah vegetation in Senegal. Journal of Environmental Management, 59, 107-120.

Martin, G.J. (1995) Ethnobotany: A Methods Manual. Chapman \& Hall, London, UK.

NeMA (National Environment Management Authority) (2002) State of the Environment Report for Uganda 2002. National Environment Management Authority, Kampala, Uganda.

Obiri, J., Lawes, M. \& Mukolwe, M. (2002) The dynamics and sustainable use of high-value tree species of the coastal Pondoland forests of the Eastern Cape Province, South Africa. Forest Ecology and Management, 166, 131-148.

Peters, C.M. (1999) Ecological research for sustainable non-wood forest product exploitation: an overview. In Non-Wood Forest Products of Central Africa: Current Research Issues and Prospects for Conservation and Development (eds T.C.H. Sunderland, L.E. Clark \& P. Vantomme), pp. 19-35. Food and Agriculture Organization, Rome, Italy.

Schippmann, U., Leaman, D.J. \& Cunningham, A.B. (2003) Impact of cultivation and gathering of medicinal plants on biodiversity: global trends and issues. In Biodiversity and the Ecosystem Approach in Agriculture, Forestry and Fisheries: Satellite Event on the Occasion of the Ninth Regular Session of the Commission on Genetic Resources for Food and Agriculture, pp. 140-167. Food and Agriculture Organization, Rome, Italy.

Shackleton, S.E., Shackleton, C.M., Netshiluvhi, T.R., Geach, B.S., Ballance, A. \& Fairbanks, D.H.K. (2001) Use patterns and value of savannah resources in three rural villages in South Africa. Economic Botany, 56, 130-146.

Sheil, D., Ducey, M.J., Sidiyasa, K. \& Samsoedin, I. (2003) A new type of sample unit for the efficient assessment of diverse tree 
communities in complex landscapes. Journal of Tropical Forest Science, 15, 117-135.

Taвuti, J.R.S. (2007) The ethnobotany and ecological status of 16 woody species of Gadumire Sub-county, Uganda. Biodiversity and Conservation, 16, 1901-1915.

Tabuti, J.R.S., Dhillion, S.S. \& Lye, K.A. (2003a) Fuelwood use in Bulamogi County, Uganda: species harvested and consumption patterns. Biomass \& Bioenergy, 25, 581-596.

Taвuti, J.R.S., Dhillion, S.S. \& Lye, K.A. (2003b) Traditional medicine in Bulamogi County, Uganda: its practitioners, users and viability. Journal of Ethnopharmacology, 85, 119-129.

TaвUti, J.R.S., Dhillion, S.S. \& Lye, K.A. (2004) The status of wild food plants in Bulamogi County, Uganda. International Journal of Food Sciences and Nutrition, 55, 485-498.

Tiсктіn, T. (2004) The ecological implications of non-timber forest products. Journal of Applied Ecology, 41, 11-21.

Twine, W.C. (2005) Socio-economic transitions influence vegetation change in the communal rangelands of the South African lowveld. African Journal of Range \& Forage Science, 22, 93-99.

UBoS (Uganda Bureau of Statistics) (2000) Statistical Abstracts, 2000. Uganda Bureau of Statistics, Kampala, Uganda.

UBoS (Uganda Bureau of Statistics) (2005) The 2002 Uganda Population and Housing Census-Main Report. Uganda Bureau of Statistics, Kampala, Uganda.

W alter, S. (2001) Non-Wood Forest Products in Africa: A Regional and National Review. Working Paper FOPW/o1/1. Food and Agriculture Organization, Rome, Italy.
W arner, K. (1999) Community Forestry Field Manual 5: Selecting Tree Species on the Basis of Community Needs. Food and Agriculture Organization, Rome, Italy.

WRI (World Resources Institute), IUCN \& UNEP (United Nations Environment Programme) in Consultation with FAO (Food and Agriculture Organization) and UNESCO (United Nations Education, Scientific and Cultural Organization) (1992) Global Biodiversity Strategy: Guidelines for Action to Save, Study, and Use Earth's Biotic Wealth Sustainably and Equitably. WRI, IUCN and UNEP, Washington, DC, USA

\section{Biographical sketches}

Jонn R.S. TAвUti is an ethnobotanist, with research interests in identifying, promoting and conserving useful plant species. He is principally interested in documenting plant use and researching the effects of such use on exploited plant populations. TAMARA TICKTIN is also an ethnobotanist, with research interests in understanding local and indigenous resource management practices and the ways in which these shape the natural environment. She is interested in applying this knowledge to the conservation of biological and cultural diversity. MARY Z. Arinaitwe is an environmental scientist interested in the sustainable management of natural resources. V.B. MUWANIKA is a conservation biologist, with research interests in seeking to understand and explain processes that lead to generation, maintenance and loss of biological diversity. 